DOI: https://doi.org/10.32839/2304-5809/2020-5-81-43

UDC 338.48

Yakovleva Tetiana, Bespalova Nataliia

Alfred Nobel University

\title{
MODERN ASPECTS OF TOURIST RESOURCES DEVELOPMENT
}

Summary. The article considers the main trends in the formation and development of tourist resources. Taking into account the purpose of the study, the main aspects of the formation of demand for a tourist product, which determines the main characteristics of tourist resources, have been proposed and justified in the article. Based on the researches of domestic scientists, the classification of recreational resources has been carried out, as well asthe feature of impracticability of the tourist product has been interpreted, which, in its turn, affects the formation of such a feature of as tourist product as virtuality. This feature allows you to get feedback from the consumer of the tourist product. It is proposed to consider a tourist product as a combination of services of linguistic and non-linguistic nature in the sphere of tourist services with the possibilities of natural, artificial and human resources.

Keywords: tourist resources, tourist product, sphere of services, tourist zone, tourist community, recreational resources.

Яковлева Т.І., Беспалова Н.В. Університет імені Альфреда Нобеля

\section{СУЧАСНІ АСПЕКТИ РОЗВИТКУ ТУРИСТИЧНИХ РЕСУРСІВ}

Анотація. Основною проблемою в сучасній Україні є соціальна напруженість, обумовлена високим рівнем безробіття серед працездатного населення. Одним зі способів розв'язку даної проблеми може стати модернізація й розвиток регіонального туристського комплексу. Це дозволить забезпечити створення нових робочих місць, буде сприяти росту добробуту суспільства, збереженню унікальної екосистеми регіону, інтенсивності культурного обміну, підвищенню рівня толерантності й, як наслідок, зміцненню стабільності в країні. Незважаючи на те, що Україна має багаті туристські ресурси, туризм так і не досяг рівня розвитку, що відповідає своїм потенційним можливостям. У цей час в'їзний туризм залишається незатребуваним внаслідок нерозвиненості інфраструктури, недосконалості механізмів державного регулювання на різних рівнях влади, відсутності мотивації для приватних інвестицій у туристські ринки й ефективних методів економічного аналізу потенціалу регіону. У зв'язку із цим можна сказати, що модернізація регіонального туристського комплексу України є актуальним завданням забезпечення відновного зростання економіки регіону й вимагає розробки ефективного інструментарію його розвитку. Дана стаття розглядає шляхи розвитку туристичних послуг у сучасних умовах України й враховуючи місцеву специфіку ринку послуг. У статті були розглянуті й роз'яснені основні шляхи формування попиту на туристичні послуги, а також аргументовано їх основні характеристики. Взявши за основу вітчизняні дослідження, була проведена класифікація можливостей відновного туризму й вплив ненав'язливості туристичних послуг на формування ознаки віртуальності послуг. Це дозволяе отримувати відгук від кінцевого споживача послуг, та використовувати цю інформацію для подальшого поліпшення послуг. Була прийнята концепція об'єднання туристичних послуг у комплекс: природне оточення, штучні комплекси будівель і людський персонал, а також різні інформаційні й консультативні технології. Такі туристичні комплекси взяті за основу побудови моделей ринку послуг. Необхідність здійснення дослідження обумовлена недостатністю наявності стратегії зародження й розвитку туризму на регіональному рівні. У статті описані способи перенесення в реальну площину моделей відносин суб'єктів і об'єктів туризму. У статті викладені основні напрямки регіональної політики для фрормування й розвитку туризму, які можуть бути використані для впровадження різних програм туристсько-рекреаційного напрямку, формування й розвитку внутрішнього й міжнародного туризму на рівні регіонів.

Ключові слова: туристичні ресурси, туристичний продукт, сфера послуг, туристична зона, туристичний контингент, рекреаційні ресурси.

Droblem statement. At the current stage, the identity of the tourism industry and its significant difference from other economic structures need a special scientific approach to the organization and management of the service process in the field of tourism services.

In particular, the need for a sound scientific approach is linked to the main typical problems of this area, such as the seasonal nature of demand for tourist product, the inability to accumulate its supply and, so to say, the virtual nature of its implementation.

Therefore, the main content of the tourist product formation is tourist resources, which a certain tourist area for rest of the tourist community depends on and which the tourist product is sold for.

The most recent scientific researches and issues analysis. The development of tourism as a socio-economic phenomenon has been considered by many researchers. Among the domestic scientists it is necessary to mention the works of Agafonova L.V. [1], Azar V.I., Dyadechko L.P. [2], Zorina V.V., Kaverina T.P., Kvartalynova V.V., Shaptala O.V. [6]. These publications provide an opportunity to draw conclusions about the existence of positive trends in the tourism industry.

Selection of previously unsolved parts of the whole problem. Research on the development of tourist resources is an important basis for improving the efficiency of services, improving and raising the quality of service provided to the tourism target market. The relevance of the definition of the tourist product in the sphere of tourism services has now started making a significant influence on the economy of the country in the conditions of market relations development. 
Aims of the article. The present article is aimed at considering the main trends in the formation and development of tourist resources. Taking into account the purpose of the study, the aim was also to propose and justify the main aspects of the formation of demand for a tourist product, which determines the main characteristics of tourist resources. Based on the research of domestic scientists, the classification of recreational resources was carried out in the article, as well as was interpreted the feature of the tourist product imprecision, which in its turn affects the formation of such a feature of the tourist product as virtuality. This feature allows you to get feedback from the consumer of the tourist product. The purpose of the article is also to propose to consider the tourist product as a set of services of linguistic and non-linguistic nature in the sphere of tourism services, with the possibilities of natural, artificial and human resources.

Statement of basic materials. Tourist resources, as the main source of the formation of the tourist product, reflect the main basis, which should exist continuously and constantly, forming its characteristic properties.

Tourist resources are a set of natural and socio-cultural complexes and their elements, which contribute to meeting the physiological and social needs of a person, restoring his/her working capacity and which, with a modern and promising structure of recreational needs as well as technical and economic opportunities, are used for direct and indirect consumption and production of a tourist product.

Today, among the significant advantages that increase the image of the tourist structure, it is possible to include the transformation of the outlined tourist territory into park areas, protected landscapes, picturesque areas and other unique and the most attractive natural places for rest and recreation. Therefore, a successful use of tourist resources in the formation of a tourist product according to the wishes of tourists is the main basis for the formation of the image of the tourist structure.

Human factors have a significant influence on the positivism of the image of the tourist structure, namely: high-quality service of the tourist community and highly qualified personnel.

It increases qualitative characteristics of processes of service of the tourist community and creates friendly atmosphere which affects the general image of tourist structure.

Besides, the formation of a tourist product needs to be carried out so that to provide tourists not only with services according to the main (basic) directions of services, but also to expand the directions of special demand of potential clients as much as possible. Such creative direction of expansion of services refers tourist structure to a special status and strengthens its image.

The unique identity of other elements of any direction of service and also elements of thrills and extreme conditions make the biggest and longenst impressions of tourists.

Thus, the tourist community first of all pays attention to the following:

- conditions of comfortable rest and accomodation (dwelling);

- providing of high-quality food satisfying different tastes of consumers;
- quality of service, qualification of personnel, service;

- availability of entertainment and game facilities and other means that form a corresponding range (class) of tourist structure among the potential customers.

Besides, the formation of positive image of tourist structure creates some additional social importance which promotes attraction of additional tourist flows to the outlined recreation area.

Thus, each tourist structure with the developed identity of tourist resources reaches qualitative image, and reasonable sense of such tourist object functioning will make a considerable contribution to the achievement of a desired goal.

The achieved level of image, in its turn, demands from the tourist structure further development and improvement of the efficiency of using the following components in its activity:

Tourism resources, expanding the range of tourism products that should include principles that meet the needs and interests of tourists;

- The sphere of services of all areas of recreation, improving the quality of customer service;

- Equipment and design of recreation and entertainment facilities, constantly expanding the infrastructure of the tourist establishment;

- Personnel capacity, its culture, education, etc., maintaining the qualitative relations of personnel with the tourist community;

- Visual agitation, advertising, thanks to the promotional campaigns with the help of which tourist product promotion and advertising are realised and the borders of the tourist market of the region and the state as a whole are expanded.

Thus, the formation of a set of tourist resources into a single whole makes the inherent quintessence of the tourist product.

It should be noted that tourist resources do not have a constant classification, although the author [4] notes that there are many classifications of tourist resources and its classification depends on taking these or those criteria as a basis. One basic is an attempt to allocate primary and secondary resources or main and secondary resources. In this regard, those resources which are used directly by tourists are referred to as primary resources.

However, despite such instability, there are some main components of tourist resources - native, artificial and human.

Main types of tourism resources.

Tourist resources have a form of material basis (natural and artificial) and a service form of socio-cultural character with a human influence factor in the sphere of tourism services.

Such a classification has no clear boundaries between the components of tourism resources, that is, there are some types of resources that relate to several components of these resources at the same time. For example, attractions result from the interaction of natural and human factors, and a concept such as "recreation" can be a part of any component of tourist resources.

Variety of recreational resources.

Natural resources include complexes of living and non-living nature. Such resources, unfortunately, have elements of destruction in their consumption, which are linked to environmental dis- 
ruption and are often exhausted. That is why such resources should be treated with caution and not exceed the reasonable limits of their restoration.

With regard to artificial resources, they need to be monitored, constantly updated, innovativated and besides that they need constant and considerable investments into their development.

Human resources are now becoming a significant potential and are seen as a strategic resource in the competition of market environment.

Considering tourism resources in terms of their use, the following areas are possible:

- natural and artificial resources provide non-linguistic tourism services;

- human resources provide language tourism services.

Taken together, these two destinations make a general tourist product. A tourist product is a set of services that is a specific virtual product that differs from a material product by a number of industry-specific features. In our case, such a destination has a tourist nature, that is, a service, as "invisible" and unremarkable product, is provided by the service personnel of the tourist institution directly to tourists in the outlined recreation area, respectively with contractual obligations in the form of documentary agreements. And such an item-service is sold not as a result of production, but as an activity $[2 ; 6]$.

Therefore, consumers cannot physically feel the tourist product after directly buying it, cannot feel it and examine it. It means that payment is made ahead of actual implementation of the product. Therefore, a customer does not have full confidence in the travel product implementation, and the purchase transaction itself for the customer is a risky investment. That is why a special trust and confidence a customer must be fully and qualitatively justified upon his/her arrival at a tourist destination or a place of rest.

Optimal development of tourist resources has a considerable range of directions and, according to the well-known specialist of the tourist industry J. Christopher Holloway "The core of tourist resources is transport, accomodation and outstanding attractions (man-made and natural)" [5]. That is, according to his classification, the main areas of service are transport services, accommodation of tourists according to the housing fund of the tourist institution and guided tours of outstanding attractions. But this list should be expanded by such obligatory service direction as food. This fact is indicated and proved by a number of specialists and researchers in both domestic [3] and international tourism industry.
In addition, each tourist structure has its own peculiarities, so to the list of some obligatory service directions it can include a special service direction, which attracts clients when choosing a tourist place of rest. And such a special direction is included into the tourist package as paid (fee-paying).

Thus, a tourist product is considered as a collection of resources of linguistic and non-linguistic nature and the advantage is provided to language ones, which make up more than $80 \%$ of the tourist product. This makes it possible in most cases to identify a tourist product with tourist services and to consider it a complex of different tourist services. Such a statement gives a right to use certain assumptions and further simplify within reasonable limits and at the permitted level the calculations of service modes and research of the results by means of diagnostic procedures in all directions of tourism services.

Tourism resources determine the formation of tourism businesses in a given region.

Thus, tourist resources have such basic properties as attractiveness, climatic conditions, accessibility, degree of research, excursion significance, landscape and environmental characteristics, socio-demographic characteristics, potential reserve and type and style of use. These resources are used for health, tourism, sports and cognitive purposes and, if properly used, bring considerable profit to the state.

Conclusions and prospects. We have found out in the article that the tourist product can be considered as a set of services of a linguistic and non-linguistic nature in the field of tourism services with the possibilities of natural, artificial and human resources. The difference between the tourist product and the traditional commodity products of production structures is its virtuality, as well as the opposite direction of sale of the goods.

Making some analysis it should be said that Ukraine has huge potential for tourism development, as the main factors showing the strengths of tourism development: significant and unique natural and recreational potential of the area, favorable geographical location, ecological well-being of the territory of Ukraine. The large number of unemployed working people; existence of the international airports. All the above factors determine the unique features that Ukraine is distinguished by. Thus, further research of the main types of tourist resources and diversity of recreational resources will make it possible to make a more accurate structure of a tourist product formation while providing a high-quality tourist product.

\section{References:}

1. Ahafonova, L.H., \& Ahafonova, O.E. (2006). Turyzm, hotelnyi ta restorannyi biznes: Tsinoutvorennia, konkurentsiia, derzhavne rehuliuvannia: navch. posib. [Tourism, hotel and restaurant business: Pricing, competition, government regulation: a textbook]. Kyiv: Znannia Ukrainy. (in Ukrainian)

2. Diadechko, L.P. (2007). Ekonomika turystychnoho biznesu [Economics of tourism business]. Kyiv: Tsentr uchbovoi literatury. (in Ukrainian)

3. Malska, M.P., \& Antoniuk, N.V. (2008). Mizhnarodnyi turyzm i sfery poslu : pidruchnyk [International tourism and services: a textbook]. Kyiv: Znannia. (in Ukrainian)

4. Pankiv, N.M. (2014). Turystychni resursy ta yikhni klasyfikatsii [Tourist resources and their classifications]. Naukovi zapysky Ternopilskoho natsionalnoho pedahohichnoho universytetu imeni Volodymyra Hnatiuka. Seriia: Heohrafiia, no. 2, pp. 93-99.

5. Khollovei, Dzh.K., \& Teilor, N. (2007). Turystychnyi biznes [Travel business]. Kyiv: Znannia. (in Ukrainian)

6. Shaptala, O. (2009). Rekreatsiia i turyzm: vzaiemozviazky, vidnosyny i problemy [Recreation and tourism: relationships, relationships and problems]. Visnyk Ukrainskoi Akademii derzhavnoho upravlinnia pry Prezydentovi Ukrainy, no. 3, pp. 395-399. 